Received: 06/05/2019

Revision: 09/10/2019

Accepted: 25/10/2019

OnlineFirst:07/01/2020

\title{
PBLPOE: A Learning Model to Enhance Students' Critical Thinking Skills and Scientific Attitudes
}

\author{
Apriza Fitriani \\ Postgraduate Student at Universitas Negeri Malang; and Biology Education Department \\ Universitas Muhammadiyah Bengkulu, Indonesia, aprizafitriani@umb.ac.id \\ Siti Zubaidah \\ Prof., Biology Department, Universitas Negeri Malang, Indonesia, \\ siti.zubaidah.fmipa@um.ac.id

\section{Herawati Susilo} \\ Prof., Biology Department, Universitas Negeri Malang, Indonesia, \\ herawati.susilo.fmipa@um.ac.id

\section{Mimien Henie Irawati Al Muhdhar} \\ Prof., Biology Department, Universitas Negeri Malang, Indonesia, \\ mimien.henie.fmipa@um.ac.id
}
The present study was an attempt to investigate the effect of Problem-Based Learning (PBL), Predict, Observe, Explain (POE), and the combination of both (PBLPOE) on students' critical thinking skills and scientific attitudes in Biology. A pretest-posttest nonequivalent control group design was employed in this study and 132 tenth-grade students from Bengkulu, Indonesia was involved. This study was carried out from February to June 2018. An essay test was administered to assess the participants' critical thinking skills, and a checklist and an interview guideline were used to observe the students' scientific attitudes. The results of the ANCOVA analysis showed that PBL, POE, and PBLPOE had an effect on the students' critical thinking skills and scientific attitudes in Biology with p- value $<0.005$. The results of the LSD test indicated that PBLPOE was not significantly different from PBL, but differed considerably from POE and conventional in improving students' critical thinking. Also, LSD test on the students' scientific attitudes showed that PBLPOE differed significantly from PBL, POE, and conventional in enhancing students' scientific attitudes. The highest post-test score was observed in the PBLPOE classroom. Therefore, PBLPOE can be used to improve students' performance in Biology.

Keywords: critical thinking skills, problem-based learning, predict observe explain, scientific attitudes, thinking skills 


\section{INTRODUCTION}

Rapid scientific and technological advances in the globalization era encourage students to acquire various skills, knowledge, and attitudes. The advancement of science also assigns teachers into various essential roles in facilitating learning, such as in contextual learning in Biology. Biology learning can be problematic for students if it only focuses on content mastery instead of the development of the students' life skills and attitudes. Contextual learning requires students to be able to apply new knowledge and skills in real-life situations. Critical thinking skills and scientific attitudes are among the essential skills and knowledge that should be prioritized by $21^{\text {st }}$-century students (Duran \& Şendağ, 2012; Ennis, 2013).

Student's thinking abilities are empowered by their skills in thinking clearly and rationally. Critical thinking is one of the higher-order thinking skills that enable someone to make a decision and conduct an appropriate action (Ennis, 2013). Critical thinking skills are part of $21^{\text {st }}$-century skills (Scott, 2015). Critical thinking help students to be autonomous and proficient in problem-solving (Zubaidah, Corebima, Mahanal, \& Mistianah, 2018). Critical thinking skills are essential and beneficial for every individual, especially in the field of education. One of the ultimate goals of education is to generate critical thinkers (Alkharusi, Sulaimani, \& Neisler, 2019) who can work effectively in society (Peter, 2012). Therefore, critical thinking skills are not only needed in school but also in the workplace in the future because these skills can improve one academic performance and success in life (Suarniati, Hidayah, \& Handarini, 2018).

Some previous related studies suggest that the majority of Indonesian students perform poorly in critical thinking (Suarniati et al., 2018). Since the teacher has not taught the students how to make the right decision and solve a problem effectively, the students faced difficulties in giving logical arguments (Suarniati et al., 2018). As a result, the students' critical thinking skills are weak. Moreover, in the classrooms where teachercentered learning is more dominant (Sahyar, Ridwan, Sani, \& Malau, 2017), the students are not encouraged to think critically nor involved actively in the learning process. Therefore, they are unable to ask analytic, synthetic, and argumentative questions. Besides, based on an observation conducted by Amin, Zubaidah, Corebima, Mahanal, 2017, Indonesian students' critical thinking skills can be categorized into the low category. The students' poor critical thinking skills indicate their inability to solve problems effectively or to deal with difficulties in connecting research findings with the theories. Not only in Indonesia, this phenomenon also occurs in other countries (Etkina \& Planinsi, 2015; Vieira \& Vieira, 2016).

Thinking skills are affected by scientific attitudes. Scientific attitudes refer to a way of thinking without prejudice (John \& Ademola, 2014). These attitudes are typically reflected in one's rational, consistent, and objective thoughts towards relevant circumstances (John \& Ademola, 2014). Scientific attitudes are signified by curiosity and critical, logical, objective, honest, and modest open-mindedness (Ali et al., 2013).

Promoting students' scientific attitudes is an important objective of a school curriculum which can be determined by the quality of learning, students' skills, teacher-student, and 
student-student interactions, and the learning atmosphere. Scientific attitudes are crucial in problem-solving that requires proof and structured procedures (Kuşdemir, Yusuf, \& Tüysüz, 2013). A scientist has to develop several scientific attributes, including curiosity, cooperation, receptiveness to new ideas, critical thinking, objectivity, honesty, and generosity (Mahulae, Sirait, \& Sirait, 2017).

Students from Indonesia (Firdaus \& Darmadi, 2017) and students from around the world were reported to have negative scientific attitudes (Potvin \& Hasni, 2014). This happens because the teacher has not trained the students to develop their scientific attitudes in the classroom. Therefore, the students have grown to be less tolerant with other students in stressful situations. Based on a survey conducted by Firdaus \& Darmadi (2017), students' scientific attitudes are categorized into the low category. The findings of the study suggest that students' lack of flexibility in classroom discussion can lead to their weak interest in learning and cooperation skills. Students' little environment-sensitivity may result from the students' absence of tolerance to their peers' difficult circumstances. Other possible causes of students' poor scientific attitudes include inadequate scientificattitudes training and ineffective learning strategies which merely focus on improving students' ability to read textbooks (Şentürk \& Özdemir, 2014).

Numerous studies have shown that students' critical thinking skills and scientific attitudes can be empowered through contextual, student centered, and constructive learning models (Qarareh, 2016). The examples of the learning models are ProblemBased Learning (PBL) and Predict, Observe, and Explain (POE). Problem-Based Learning (PBL) accommodates students' investigations, problem-solving, and activities of integrating theories and practices (Sahyar et al., 2017). PBL consists of several stages that include orientation of problems, students' organization, investigation, presentation, and reflection (Arends, 2012). Some research findings have proved that PBL can improve students' critical thinking skills (Sahyar et al., 2017) and students' scientific attitudes (Abdullah, Tarmizi, \& Abu, 2010).

PBL is a learning model that encourages learners to understand a concept through selfdiscovery. PBL classroom activities connect directly to real-world issues which can optimize thinking skills and provide an opportunity for the students to implement their knowledge to solve a problem (Arends, 2012).

Predict, Observe, and Explain (POE) is a learning model initially developed for science education. As suggested by Bilen, Özel \& Köse (2016), POE springs from the constructivist theory, which emphasizes the importance of exploring students' background knowledge. POE consists of three phases that are predict (formulating temporary predictions), observe (do an investigation), and explain (present the results of the study and compare them with the predictions) (Bowen \& Haysom, 2014). Research shows that POE is effective in promoting students' scientific attitudes (Şeşen \& Mutlu, 2010) and students' critical thinking (Adebayo \& Olufunke, 2015).

Students in the POE classrooms are provided with an orientation to a phenomenon and a chance to predict the outcome by considering ideas on what is going to happen and using those ideas to make a prediction. The prediction and the reasons for it are written 
down on the provided worksheet. However, several studies also revealed the shortcomings of PBL (Batdi, 2014; Demirel \& Dagyar, 2016) and POE (Furqani, Feranie \& Winarno., 2018). For example, Kuşdemir et al. (2013); Üstün \& Eryilmaz (2014) could not prove the effectiveness of PBL in improving students' scientific attitudes. The implementation of PBL individual or group activities does not always result in the improvement of students' scientific attitudes in biology learning at every level of education. Also, Furqani et al. (2018) also reported that POE did not affect students' critical thinking skills. The students had to deal with contextual problems and faced difficulties in formulating questions based on phenomena.

It is assumed that POE can overcome PBL's weaknesses and vice versa. PBL provides students with authentic problems and formulation of problems, but not with prediction. Therefore, the prediction activity that is accommodated in POE can help improve PBL syntax. Making predictions allows students to explore their curiosity about an issue and generate ideas based on experiences (Adebayo \& Olufunke, 2015). Comparing the results of observation with prior predictions is a way to establish one's accuracy, understanding, and rationality an object (Bilen et al., 2016).

Based on the empirical facts outlined in the previous sections, it can be concluded that the combination of PBL and POE (PBLPOE) is potentially useful in improving students' critical thinking skills and scientific attitudes. The PBLPOE model consisted of the following phases: orientation of the problem, organization of students, prediction, investigation/observation, explanation, and analysis and evaluation.

\section{LITERATURE REVIEW}

\section{Critical Thinking Skills}

Critical thinking skills are complex skills that enable someone to obtain information, collect data, and evaluate findings effectively (Ennis, 2011; Klein, 2011) to generate a satisfactory conclusion (Peter, 2012). The development of critical thinking skills may result in improved quality of thinking that is to involve reasoning and logic in solving problems (Zubaidah et al., 2018). Critical thinking skills are essential for university students to perform well at school and in the work field (Costa \& Kallick, 2014).

According to some experts, a critical thinker has typically the ability to interpret, analyze, evaluating problems using evidence, concepts, methodology, and criteria that can be used as the basis for making a decision (Carriger, 2015). Also, to think critically means to be involved in the mental process of applying concepts, analyzing, synthesizing, evaluating results, and reflecting (Alkharusi et al., 2019). Research shows that a classroom environment that facilitates thinking activities can develop students' thinking skills (Vieira \& Vieira, 2016). Students who learn through contextual problems can increase their critical thinking performance.

\section{Scientific Attitudes}

Attitudes involve knowledge of cognition, values, self-esteem, feelings, behaviors towards particular subjects or situations (Vossen et al., 2018). Attitudes represent evaluations related to oneself, objects, and problems. Scientific attitudes are often 
associated with attitudes toward science. Scientific attitudes include the desires to know and understand, seek information, verify, and consider consequences (Hacieminoglu, 2016).

Scientific attitudes play a significant role in learning because they influence learning outcomes. Someone with an excellent scientific attitude will not receive any unproven and illogical information which is processed without wisdom and has a strong belief in her/himself (John \& Ademola, 2014). Scientific attitudes can be measured through one's achievement in science, self-concept, interest in science, and motivation for science (Alam, 2017).

\section{Problem Based Learning}

PBL is problem-oriented learning that stimulates high-level thinking skills to find solutions to problems (Arends, 2012). PBL is also defined as learning that encourages students to acquire essential knowledge and concepts from the subject matter and to develop inquiry and high-level thinking skills (Carriger, 2015).

PBL can provide conducive learning so that it can promote students' critical thinking skills. PBL challenges students to solve problems. Therefore, this type of learning is more effective than conventional learning (Vieira \& Vieira, 2016). The results of the research by Applin, Williams, Day, Buro (2011) explains that PBL has the potential to increase students' knowledge and reflective thinking in solving contextual problems.

\section{Predict, Observe, Explain}

POE is constructivism-based learning that helps build students' cognitive structures. POE engages students in developing ideas through "predicting" activities, exploring the sources of knowledge through investigation, reflecting ideas, and conducting meaningful discussions through "explain" actions (Şeşen \& Mutlu, 2016).

Research by Adebayo \& Olufunke (2015) has successfully proven that POE scores differed significantly from that of conventional learning. In POE, students are encouraged to discuss arguments, increase the level of student information, and concept understanding. POE is useful in developing students' ideas and skills (Şeşen \& Mutlu, 2016). POE accommodates meaningful learning that can build students' scientific attitudes as well as motivation (Bilen et al., 2016).

\section{Aim of the Research}

The objectives of this study were to investigate the effects of PBL, POE, and PBLPOE on critical thinking skills and students' scientific attitudes towards Biology.

\section{METHOD}

\section{Research Design and Participant}

The current study was conducted as a quasi-experiment employing a pretest-post-test nonequivalent control group design (Cohen, Manion, \& Morrison, 2011), which can be seen in Table 1 . The independent variables of this study were the learning models (PBL, 
POE, PBLPOE, and conventional) implemented in four treatment classes. The participants from each class were selected randomly. The participants consisted of 132 tenth graders from Bengkulu, Indonesia.

Table 1

Research Design

\begin{tabular}{lllllc}
\hline Pretest & $\begin{array}{l}\text { Treatment } \\
\text { Group }\end{array}$ & Name of school & Class & $\begin{array}{l}\text { Number of } \\
\text { students }\end{array}$ & Posttest \\
\hline $\mathrm{O}_{1}$ & PBL & SMAN 5 & X IPA 4 & 36 & $\mathrm{O}_{2}$ \\
\hline $\mathrm{O}_{3}$ & POE & SMAN 4 & X IPA 3 & 30 & $\mathrm{O}_{4}$ \\
\hline $\mathrm{O}_{5}$ & PBLPOE & SMAN 5 & X IPA 1 & 34 & $\mathrm{O}_{6}$ \\
\hline $\mathrm{O}_{7}$ & Conventional & SMAN 6 & X IPA 1 & 32 & $\mathrm{O}_{8}$ \\
\hline
\end{tabular}

\section{Instrument}

Syllabus, lesson plans, student worksheets, and tests for critical thinking and scientific attitudes were developed for data collection. The critical thinking evaluation package consisted of a 15-item essay test and a rubric for scoring students' answers, which were measured according to Ennis (2011). The tests for validity and reliability of the instruments were conducted. The validity test of the instruments was performed to examine whether the instruments measured what needed to be measured using Pearson Product Moment (Creswell, 2012), while the reliability test of the instruments was performed using Cronbach's Alpha. The test had been confirmed valid (0.950) and reliable (0.958). These indicators would assess students' ability in providing simple explanations, determining bases for decision making, drawing an inference, clarifying ideas, creating arguments and integration, and organizing strategies and tactics.

The students' scientific attitudes were observed using a checklist, and an interview was conducted to the students to obtain more detailed information related to their scientific attitudes. Observation sheets for measuring the students' scientific attitudes used Likert scales 1-4; score 4 for four indicators fulfilled, score 3 for three indicators fulfilled, score 2 for two indicators fulfilled, and score 1 for one indicator fulfilled. Aspects to measure included students' curiosity, honesty, cooperation, thoroughness, responsibility, discipline, and sensitivity to the environment (modified from John \& Ademola, 2014; Panneerselvam \& Muthamizhselvan, 2015). The observation checklist and interview schedule had been valid ( 0.970 and 0.955 , respectively).

\section{Procedures}

The present study was carried out for one academic from February to June 2018 in "Plantae, Animalia, Ecosystem, and Environmental Pollution" classrooms. The steps of conducting learning in each classroom are explained as follows. The stages of PBL were as follows: (1) the students actively formulated questions, (2) they sat in groups and the teacher-directed them to make questions relevant to the learning objectives, (3) the teacher facilitated the students' group and individual investigations, (4) the teacher encouraged the students to present the results of the investigations, and (5) the teacher guided the students to reflect and evaluate the learning process. 
Unlike PBL, learning in the POE classroom was carried out in three phases: (1) the teacher explained the background of a situation so that the students could make some relevant predictions. The students were able to make appropriate predictions because the phenomena were explained through questions on the worksheets, (2) the teacher facilitated the students' investigations, and (3) the teacher provided scaffolding so that the students were able to discuss the comparison between the results of the investigation and predictions.

On the other hand, PBLPOE syntax (which was the combination of PBL and POE learning steps) consisted of six main activities: (1) the teacher distributed a text and the students actively formulated questions based on the book, (2) the students were guided to sit in groups and select appropriate questions to discuss, (3) the teacher helped the students make predictions based on the problems, (4) the teacher facilitated the students' group and individual investigations, (5) the students presented the results of the investigation and compare them with the predictions, and (6) the teacher together with the students reflected on the process and evaluated the available solutions. In the conventional learning, (1) the teacher directly delivers the materials, (2) the teacher opens a question and answer session, (3) the teacher guides the students to conduct classroom discussion, (4) the teachers concludes the lesson and the students pays attention to it. At the end of the class, the teacher gives the students an assignment related to the materials that are going to be studied in the next meeting.

\section{Data Analysis}

The research data were analyzed using ANCOVA and the LSD (Least Significant Difference) test with SPSS for windows version 22.0. Before the analysis, the normality and homogeneity of the data were examined. Normality test was conducted using the One-Sample Kolmogorov-Smirnov Test, and homogeneity test was performed using Levene's Test. After that, ANCOVA and the LSD test were run to investigate the effect of PBLPOE on the students' critical thinking skills and scientific attitudes. LSD test was performed to investigate the significance level of the significant learning model.

\section{FINDINGS}

The Results of the Normality Test and Homogeneity Test of the Students' Critical Thinking Skills and Scientific Attitudes

The results of the normality and homogeneity tests of the students' critical thinking skills and scientific attitudes are presented in Table 2.

Table 2

The Results of the Normality and Homogeneity Tests of the Students' Critical Thinking Skills and Scientific Attitudes

\begin{tabular}{lcccc}
\hline \multirow{2}{*}{\multicolumn{1}{c}{ Treatment Group }} & \multicolumn{2}{c}{ Normality } & Homogeneity \\
\cline { 2 - 5 } & $\mathrm{N}$ & Sig & Skor Levene Test & Sig \\
\hline Critical thinking pretest & 98 & 0.000 & 1.066 & 0.368 \\
\hline Critical thinking post-test & 98 & 0.175 & 1.181 & 0.321 \\
\hline Scientific attitudes pretest & 98 & 0.200 & 3.113 & 0.051 \\
\hline Scientific attitudes post-test & 98 & 0.210 & 5.193 & 0.060 \\
\hline
\end{tabular}


Table 2 suggests that the students' scores on critical thinking and scientific attitudes were distributed normally and homogeneous (level of significance $>0,05$ ).

\section{The Effects of PBL, POE, PBLPOE, and Conventional Learning on Students' Critical Thinking Skills}

The effects of the learning models on the students' critical thinking skills were recorded in Table 3.

Table 3

The Results of the ANCOVA Analysis (Critical Thinking Skills)

\begin{tabular}{llllll}
\hline Source & Type III Sum of Squares & df & Mean Square & F & Sig. \\
\hline Corrected Model & $18603.435^{\mathrm{a}}$ & 4 & 4650.859 & 75.706 & .000 \\
\hline Intercept & 34594.702 & 1 & 34594.702 & 563.130 & .000 \\
\hline Xcritical & 38.348 & 1 & 38.348 & .624 & .431 \\
\hline Class & 18519.966 & 3 & 6173.322 & 100.489 & .000 \\
\hline Error & 5713.254 & 93 & 61.433 & & \\
\hline Total & 503159.650 & 98 & & & \\
\hline Corrected Total & 24316.689 & 97 & & & \\
\hline
\end{tabular}

R Squared $=.765$ (Adjusted $\mathrm{R}$ Squared $=.755$ )

Table 3 presents information about the difference between the learning models $\left(\mathrm{F}_{\text {calculated }}\right.$ $=100.489$ with $p$-value $=0.000$. $p$-value $<\alpha(\alpha=0.05))$. Hence, the hypothesis that mentioned that the learning models affected the students' critical thinking skills was accepted. After proving the hypothesis, LSD test was run, and the results were presented in Table 4.

Table 4

The Results of the LSD Test (Critical Thinking Skills)

\begin{tabular}{llllllll}
\hline Class & Pretest & Post-test & Difference & Increase & Corrected Item-Total & \multicolumn{2}{c}{ LSD Notation } \\
\hline Conventional & 23.394 & 48.271 & 24.877 & $106.34 \%$ & 48.144 & a & \\
\hline POE & 22.424 & 73.182 & 50.758 & $226.35 \%$ & 72.962 & $\mathrm{~b}$ \\
\hline PBL & 29.807 & 77.833 & 48.026 & $161.12 \%$ & 78.318 & $\mathrm{c}$ \\
\hline PBLPOE & 22.753 & 83.188 & 60.435 & $265.61 \%$ & 82.999 & $\mathrm{c}$ \\
\hline
\end{tabular}

The results of the LSD test showed that PBLPOE was not significantly different from PBL. However, there was a significant difference found between PBLPOE, POE, and conventional. POE differed significantly from PBLPOE, PBL, and conventional. The highest average post-test score was found in the PBLPOE classroom (83.19), followed by PBL (77.83), POE (73.18), and conventional (48.27).

The highest average score was achieved by PBLPOE (82.99), followed by PBL (78.32), POE (72.96), and conventional (48.15). In details, the average scores of PBL, POE, 
PBLPOE, and conventional on critical thinking were presented in Figure 1.

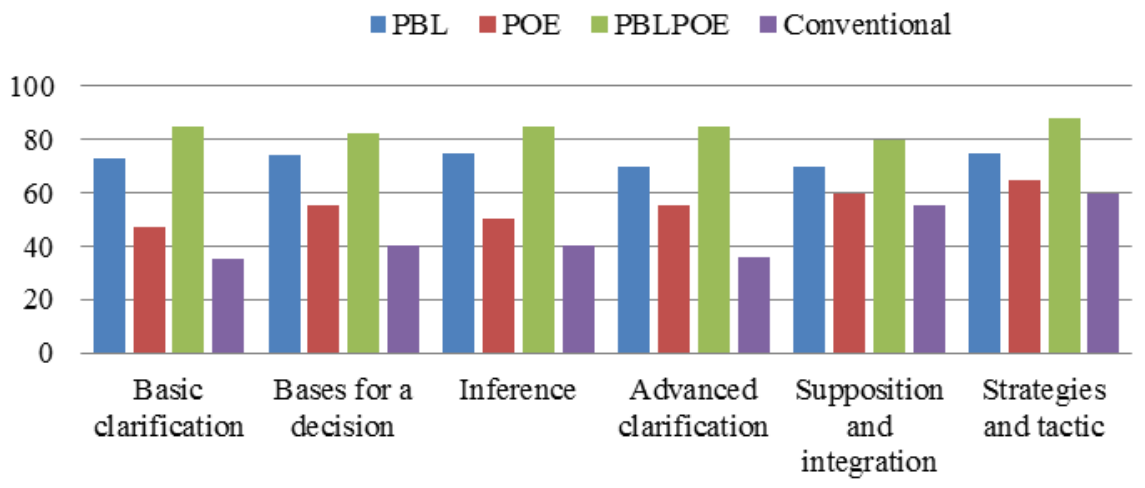

Figure 1

The Average Scores of PBL, POE, PBLPOE, and Conventional on Critical Thinking Skills

Figure 1 suggested that PBL, POE, PBLPOE, and conventional scores for basic clarification were $73 \%, 47 \%, 85 \%$, and $35 \%$, while for bases for a decision were $74 \%$, $55 \%, 82 \%$ and $40 \%$, and for inference were $75 \%, 50 \%, 85 \%$, and $40 \%$, respectively. On the other hand PBL, POE, PBLPOE, and conventional achieved relatively higher scores in advanced clarification (70\%, 55\%, 85\%, 36\%), supposition and integration $(70 \%, 60 \%, 80 \%, 55 \%)$, and strategic and tactic which were $(75 \%, 65 \%, 88 \%$, and $60 \%)$.

The Effects of PBL, POE, PBLPOE, and Conventional Learning on Students' Scientific Attitudes

The results of the ANCOVA analysis on the effects of the learning models on the students' scientific attitudes were presented in Table 5.

Table 5

The Results of the ANCOVA Analysis (Scientific Attitudes)

\begin{tabular}{llllll}
\hline Source & $\begin{array}{l}\text { Type III Sum } \\
\text { of Squares }\end{array}$ & df & $\begin{array}{l}\text { Mean } \\
\text { Square }\end{array}$ & F & Sig. \\
\hline Corrected Model & $17168.279^{\mathrm{a}}$ & 4 & 4292.070 & 158.731 & .000 \\
\hline Intercept & 5464.068 & 1 & 5464.068 & 202.074 & .000 \\
\hline X attitudes & 466.367 & 1 & 466.367 & 17.247 & .000 \\
\hline Class & 13605.665 & 3 & 4535.222 & 167.723 & .000 \\
\hline Error & 2514.715 & 93 & 27.040 & & \\
\hline Total & 551035.363 & 98 & & & \\
\hline Corrected Total & 19682.994 & 97 & & & \\
\hline R Squared $=.872$ (Adjusted R Squared $=.867)$ & & & & \\
\hline
\end{tabular}


Based on the results of the ANCOVA analysis presented in Table 5, it was found that the learning models affected the students' scientific attitudes $\left(\mathrm{F}_{\text {calculated }}=167.723\right.$ with $p$ value $=0.000$. $p$-value $<\alpha(\alpha=0.05))$. Therefore, $\mathrm{H}_{0}$, which stated that there was no difference in the students' scientific attitudes was rejected. To investigate the significance of each learning model, LSD test was conducted. The results of the test were recorded in Table 6.

Table 6

The Results of the LSD Test (Scientific Attitudes)

\begin{tabular}{llllllll}
\hline Class & Pretest & Post-test & Difference & Increase & $\begin{array}{l}\text { Corrected } \\
\text { Item-Total }\end{array}$ & $\begin{array}{l}\text { LSD } \\
\text { Notation }\end{array}$ \\
\hline Conventional & 47.259 & 52.760 & 5.500 & $11.64 \%$ & 53.795 & $\mathrm{a}$ & \\
\hline POE & 49.818 & 79.265 & 29.446 & $59.11 \%$ & 79.453 & $\mathrm{~b}$ \\
\hline PBL & 51.000 & 80.307 & 29.307 & $57.47 \%$ & 80.105 & $\mathrm{~b}$ \\
\hline PBLPOE & 53.913 & 85.209 & 31.296 & $58.05 \%$ & 84.043 & & $\mathrm{c}$ \\
\hline
\end{tabular}

The results of the LSD test (Table 6) indicated that PBLPOE differed significantly from PBL, POE, and conventional. There was no significant difference between PBL and POE. However, the difference between PBL and conventional was quite significant. POE differed significantly from PBLPOE, and conventional. The highest score in the post-test was reported by PBLPOE (85.20), followed by PBL (80.30), POE (79.26), and conventional (52.76). The average scores of the students' scientific attitudes can be seen in Figure 2.

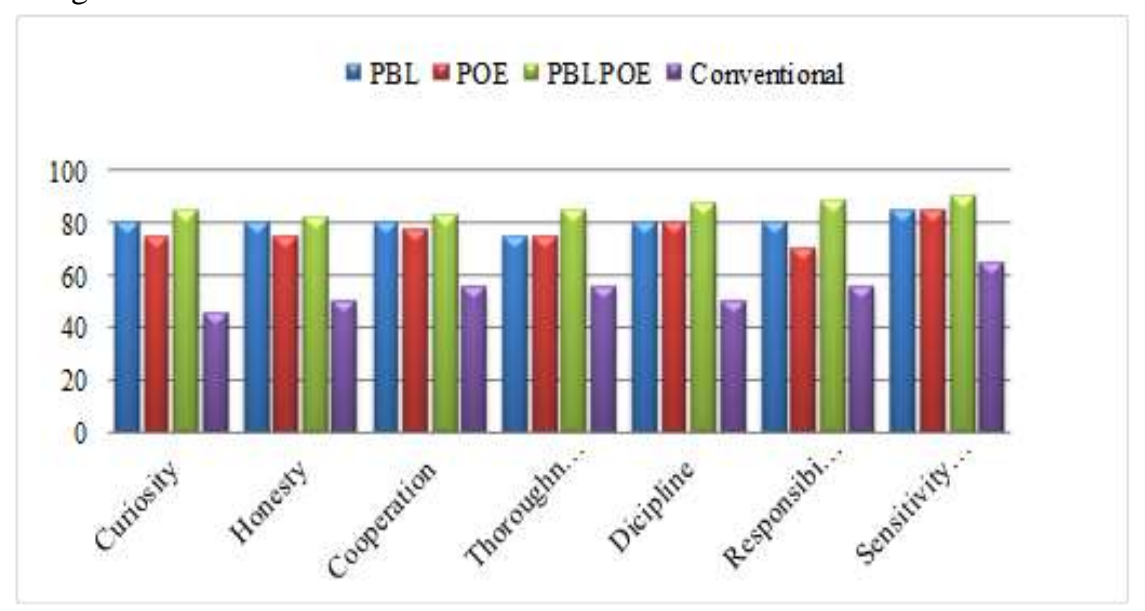

Figure 2

The Average Scores of PBL, POE, PBLPOE, and Conventional on Scientific Attitudes

Figure 2 indicated that PBL, POE, PBLPOE, and conventional scored 80\%, 75\%, 85\% and $45 \%$ in curiosity and $80 \%, 75 \%, 82 \%$, and $50 \%$ in honesty. These classes obtained $80 \%, 77 \%, 83 \%$, and $55 \%$ in cooperation and $75 \%, 75 \%, 85 \%$, and $55 \%$ in thoroughness. Relatively higher scores were observed in discipline (80\%, 80\%, 87\%, 
and $50 \%)$, responsibility (80\%, 70\%, 88\% and 55\%), and sensitivity to the environment $(85 \%, 85 \%, 90 \%$, and $65 \%)$.

\section{DISCUSSION}

The Effects of PBL, POE, PBLPOE, and Conventional Learning on Students' Critical Thinking Skills

The results of the study showed that learning models affected the students' critical thinking skills in biology. However, it was evident that PBLPOE gave the highest contribution to the students' critical thinking skills compared to PBL and POE. PBLPOE engaged the students in formulating questions based on a text, such as: "What could happen if the level of $\mathrm{O}_{2}$ in the ocean experiences a decrease?". The text could be found in the worksheet, and it discussed a topic about "Plantae, Animalia, Ecosystems, and Environment". Through this activity, the students had developed one of the indicators of critical thinking skills that are "providing simple clarification" for example: "a decrease in the amount of oxygen in the ocean will result in disruption of marine ecosystems and food chains because the majority of marine biota depend on their lives on oxygen. Low oxygen levels will lead to inhibiting the growth of fish and other marine animals and even lead to the death of the animals". The students' success in accomplishing this indicator suggested that the students were able to explore their experiences based on the given phenomenon. This finding is in line with that of Vieira \& Vieira (2016), who suggests that the first step to building students' critical thinking skills is through learning experiences. Learning experiences are ongoing learning processes. Likewise, Peter (2012) conclude that students' critical thinking skills can be developed through "formulating a problem" activities.

PBLPOE phase that ma contributes to the improvement of the students' critical thinking skills is the investigation phase. The investigation phase engages the students in actively searching for information to solve various problems. The students are allowed to conduct group discussion on the information. This activity involves the students in an exchange of ideas. Research by Zubaidah et al. (2018) shows that the interaction between group members encourages an exchange of ideas which can lead to the improvement of their critical thinking skills.

Besides, the "explain" phase in PBLPOE engaged the students actively in discussions and in explaining the comparison between the results of the investigations and the predictions. At the explained stage, the students are asked to present the results of their investigation. Afterward, each of the groups is invited to a question and answer session. The explain stage also improves the students' critical thinking skills. This activity can empower several indicators of critical thinking skills, namely basic clarification, inference, supposition, and integration. The results of the Etkina \& Planinsic study (2015) showed that students are allowed to think through group discussion and providing arguments. Critical thinking skills can be obtained by exploring phenomena, utilizing various sources to find solutions to problems, and providing explanations.

PBLPOE did not differ significantly from PBL in improving the students' critical thinking skills. The statistical analysis of the students' pretest and post-test showed that 
PBLPOE achieved the highest scores compared to PBL. Both learning models are based on the constructivism theory that emphasizes on students' active involvement in the search for knowledge. Students' active engagement in the pursuit of insights will lead to their increased skills in thinking critically. Constructivism-based learning helps construct student knowledge based on their prior knowledge. The students perform an interactive process to exchange information as well as to compare, examine, and redefine their knowledge with other group members (Bada \& Olusegun, 2015).

Constructivist learning is meaningful and useful to improve students' higher-order thinking (Qarareh, 2016). According to Klein (2011), critical thinking skills contain several components, including analyzing and applying concepts and making decisions. Higher-Order thinking skills (HOTS) require students to manipulate information and ideas as a way to transform knowledge and implement it, such as when the student integrate facts and ideas into synthesizing, generalizing, explaining, and interpreting information.

Critical thinking skills indicators, including exploring questions, analyzing arguments, integrating information to find solutions to problems, and making conclusions were accommodated in PBLPOE and PBL. Therefore, the students' scores in these aspects were categorized into the high category. PBLPOE and PBL classroom activities encourage the students to use reasoning in analyzing a phenomenon, creating an argument, drawing a conclusion, and solving a problem. Duran \& Şendağ (2012) argue that critical thinkers deepen their knowledge by exploring sources to find solutions, analyzing information logically, and providing wise and logical decisions. Students who can think critically are also able to combine information and make interpretations (Duran \& Dökme, 2016).

PBLPOE and PBL allow students to reflect on themselves and evaluate the results of the problem-solving process. The evaluation phase helps students to discover new knowledge. For instance, "in the beginning, the students categorized Hydra into Plant because it germinates, but during the learning and evaluation processes, the students discovered new knowledge that Hydra can be categorized into Animal". The successful implementation of learning was also caused by the provision of authentic problems (Qarareh, 2016), and feedback on every meeting (Costa \& Kallick, 2014). Feedback results from the evaluation process carried out by the students and the teacher.

There was a significant difference found between PBLPOE and POE in improving students' critical thinking skills. It was evident that PBLPOE steps contributed a lot to the development of the students' critical thinking skills through the process of analyzing phenomena, doing deduction and induction with various sources of information such as from the internet, books, or modules, and making wise decisions. Duran \& Şendağ (2012) explain that students' critical thinking skills can be developed through the process of exploring and analyzing scientific phenomena, having scientific discussions (e.g., buzz group discussion, panel discussion, symposium, seminar) and working collaboratively with peers. Analyzing the causes and solutions of problems, presenting information, and finally reaching conclusions are things needed to empower students' thinking skills (Applin et al., 2011). 
PBL, POE, PBLPOE were significantly different from conventional learning. The teacher in the conventional class was not able to facilitate the development of the students' critical thinking skills because the teacher only focused on transferring knowledge to the students. Transferring knowledge to the students means that the teacher only delivers information to the students without involving them actively in the learning process. There was no reflection activity in the classroom. Also, questions provided by the teacher did not help students to think critically, that is to think at the level of analyzing, synthesizing, and evaluating (Lloyd \& Bahr, 2010).

\section{The Effects of PBL, POE, PBLPOE, and Conventional Learning on Students'} Scientific Attitudes

The results of the study showed that PBL and POE contributed more to the students' scientific attitudes compared to conventional learning. However, the PBLPOE model had a higher potential to improve the students' scientific attitudes compared to PBL and POE. The "prediction making" stage in PBLPOE allows students to enhance their curiosity. The prediction activity can enhance student curiosity by asking them to predict what could happen next before they conduct an investigation. This activity, where the students are encouraged to stated their ideas about what is happening and provide reasons for it, according to Vossen et al. (2018), can drive students to investigate more deeply.

PBLPOE was significantly different from PBL because PBLPOE was able to improve the students' honest and thorough attitudes through the "observe" stage. Lloyd \& Bahr (2010) highlight the importance of students' accuracy in collecting data and facts to solve problems. Also, a scientist must perform an objective attitude so that findings can be interpreted fairly and correctly (Dudo \& Besley, 2016). In addition, the "explain" stage in PBLPOE could accommodate the students' cooperative, responsible, and discipline attitudes because the students were required to make the right decisions in the end, for example, "global warming occurs due to climate change which causes a decrease in the number of oxygen levels in the oceans and threatens the existence of marine ecosystems. Global warming can be overcome through conservation by cultivating various types of seaweed because, in addition to having a high economic value, algae also have the potential to absorb $\mathrm{CO}_{2}$ ". Cooperative and objective students will be able to achieve a correct or accurate solution (John \& Ademola, 2014).

Another phase of PBLPOE that makes it different from other learning models is "orientation of the problem". At this stage, students are encouraged to show curiosity about the given problem. Curiosity is characterized by the desire to understand the situation and try to find out about the observed phenomenon (John \& Ademola, 2014). Based on the results of the interviews with 15 students, the students were very enthusiastic in following the learning process and looking for answers from various relevant sources such as books, articles found on the internet. Curiosity, open-mind, and objectivity play a crucial role in the learning process. In other words, there is a relationship between curiosity and student academic performance (Panneerselvam, \& Muthamizhselvan, 2015). In the "organize student activities" phase, students in their groups need to specify which problems should be discussed so that learning objectives 
can be achieved. This process requires a collaborative process between the studentsstudent and the student-teacher before the students conduct an investigation. Other factors that may also influence students' scientific attitudes include student-student and student-teacher interactions and classroom atmosphere (Abdullah et al., 2010)

The results of the study showed that PBL was not significantly different from POE in empowering the students' scientific attitudes. Both PBL and POE activities enable students to develop curiosity, honesty, cooperation, thoroughness, and responsibility. The two learning models contain aspects of scientific attitudes. The results of the interviews also revealed that the students felt that their scientific attitudes could be developed through the implementation of PBL and POE. Likewise, several studies have also proven the effectiveness of PBL in improving students' scientific attitudes (Batdi, 2014) and POE (Şeşen \&Mutlu, 2010). The improvement of the students' critical thinking skills and scientific attitudes is indicated by the improvement of their scores on the pretest and post-test.

Conventional learning differed significantly from PBL, POE, and PBLPOE in empowering the students' scientific attitudes, indicated by the students' low scores on almost all the aspects of scientific attitudes. In the conventional classroom, learning relied solely on the textbook, memory, and the question and answer method that resulted in the students' passiveness. The students were not given a chance to find a solution to their problems from different sources. The students were unable to state their problems. The students only wrote down information delivered by the teacher. As a result, their scientific attitudes could not be empowered. The results of the interviews uncovered the fact that the teacher used the textbook as the primary source of learning. The students also explained that they only obtained information from the teacher and acquired knowledge by memorizing concepts. These findings were corroborated with those by Hacieminoglu (2016), who showed that memorization could negatively affect student achievement and attitudes. Ali et al. (2013) also add that students' dependence on textbooks may result in lowering their scientific attitudes. Besides, learning styles and the learning environment can also affect students' scientific attitudes (Alam, 2017).

The results of the study showed that PBLPOE was effective in improving the students' critical thinking skills and scientific attitudes. Therefore, the implementation of PBLPOE in Biology classrooms is highly recommended, especially to enhance students' critical thinking skills and scientific attitudes. Statistically, PBLPOE was significantly different from PBL, POE, and conventional. The PBLPOE average post-test score showed the highest improvement compared to the other learning models. However, this study only focused on a particular topic in Biology that is Plantae, Animalia, Ecosystem, and Environmental Pollution. This study was conducted in the even semester in the 2017/2018 academic year. There were only 132 students involved in this study, and they were all coming from senior high schools. The study was conducted for one semester, and it only covered two variable, critical thinking skills, and scientific attitudes. Therefore, to generate more accurate and insightful results, further research needs to be conducted. 


\section{CONCLUSION}

The results of the study showed that (1) the learning models (implemented in this study) had an effect on the students' critical thinking skills and scientific attitudes with pvalue $<0.005$; (2) PBLPOE had a more significant effect on the students' critical thinking skills compared to PBL and POE with average scores of 83.19; (3) there was no significant difference between PBLPOE and PBL in improving the students' critical thinking skills; and (4) The highest score on scientific attitudes was observed in the PBLPOE classroom with a score of 85.20. These findings suggest that PBLPOE and PBL can be used to promote students' critical thinking skills in the classroom. Critical thinking skills and scientific attitudes are essential components that need to be mastered by students. To investigate more about the potentials of PBLPOE, further research can be conducted at different levels of education, to different groups of students, and using different variables.

\section{ACKNOWLEDGMENTS}

Authors would like to thank the Indonesian Ministry of Research, Technology, and Higher Education and Indonesia Endowment Fund of Education (LPDP) as the sponsors of this study with contract No.FR2712018124910.

\section{REFERENCES}

Abdullah, N. I., Tarmizi, R. A., \& Abu, R. (2010). The effects of problem based learning on mathematics performance and affective attributes in learning statistics at form four secondary level. Procedia Social and Behavioral Sciences, 8, 370-376 doi:10.1016/j.sbspro.2010.12.052.

Adebayo, F., \& Olufunke, B. T. (2015). Generative and predict-observe-explain instructional strategies: Towards enhancing basic science practical skills of lower primary school pupils. International Journal Elementary Education, 4(4), 86-92 doi: 10.11648/j.ijeedu.20150404.12.

Alam, Q. (2017). Impact of the school outreach tour program of Citizens Archive of Pakistan on students' perceptions and attitudes. International Journal of Instruction, 10(1), 289-306. doi: 10.12973/iji.2017.10118a.

Ali, M. M., Yager, R. E., Hacieminoglu, E., \& Caliskan, I. (2013). changes in student attitudes regarding science when taught by teachers without experiences with a model professional development program. School Science and Mathematics, 113(3), 109-119. https://doi.org/10.1111/ssm.12008.

Alkharusi, H. A., Sulaimani, H. A., \& Neisler, O. (2019). Predicting critical thinking ability of Sultan Qaboos university students. International Journal of Instruction, 12(2), 491-504. https://doi.org/10.29333/iji.2019.12231a.

Amin, A. M., Zubaidah, S., Corebima, A.D., \& Mahanal, S. (2018). The critical thinking skills profile of preservice biology teachers. Proceedings of the 3rd International Conference on Education and Training, Series: Advances in Social Science, Education and Humanities Research (vol 128). https://doi.org/10.2991/icet-17.2017.30 
Applin, H., Williams, B., Day, R., \& Buro, K. (2011). A comparison of competencies between problem-based learning and non-problem-based graduate nurses. Nurse Education Today, 31(2), 129-134. https://doi.org/10.1016/j.nedt.2010.05.003.

Arends, R. I. (2012). Learning to teach. New York. McGraw-Hill.

Bada., \& Olusegun, S. (2015). Constructivism learning theory: A paradigm for teaching and learning. IOSR Journal of Research \& Method in Education (IOSR-JRME), 5(6), 66-70. doi: 10.9790/7388-05616670

Batdi, V. (2014). The effects of a problem based learning approach on students' attitude levels: A meta-analysis. Educational Research and Reviews, 9(9), 276-279. doi: 10.5897/ERR2014.1771.

Bilen, K., Özel, M., \& Köse, S. (2016). Using action research based on the predictobserve-explain strategy for teaching enzymes. Turkish Journal of Education, 5(2), 72 81. doi:10.19128/turje.70576.

Bowen, M., \& Haysom, J. (2014). Predict, observe, explain activities enhancing scientific understanding. USA: NSTA Press.

Carriger, M. S. (2015). PBL and management development-empirical and theoretical considerations. The International Journal of Management Education, 13(3), 249-259. http://dx.doi.org/10.1016\%2Fj.ijme.2015.07.003.

Cohen, L., Manion L., \& Morrison, K. (2011). Research methods in education. New York: Routledge

Costa, A., \& Kallick. B. (2014). Dispositions: Reframing teaching and learning. Thousand Oaks, CA: Corwin Press.

Creswell, J. W. (2012). Educational research: Planning, conducting, and evaluating quantitative and qualitative research. Boston, MA: Pearson.

Demirel, M., \& Dağyar, M. (2016). Effects of problem-based learning on attitude: A meta-analysis study. Eurasia Journal of Mathematics, Science and Technology Education, 12(8), 2115-2137 doi: 10.12973/eurasia.2016.1293a.

Dudo, A., \& Besley, J. C. (2016). scientists' prioritization of communication objectives for public engagement. PLoS ONE, 11(2), 1-18. https://doi.org/10.1371/journal.pone.0148867.

Duran, M., \& Dökme, I. (2016). The effect of the inquiry-based learning approach on student's critical-thinking skills. Eurasia Journal of Mathematics, Science and $\begin{array}{lll}\text { Technology Education, } & \text { 12(12), 2887-2908. }\end{array}$ https://doi.org/10.12973/eurasia.2016.02311a.

Duran, M., \& Şendağ, S. (2012). A preliminary investigation into critical thinking skills of urban high school students: Role of an IT/STEM program. Creative Education, 3(2), 241-250 http://dx.doi.org/10.4236/ce.2012.32038. 
Ennis, R. H. (2011). The nature of critical thinking: Outlines of general critical thinking dispositions and abilities. Retrieved from https://education.illinois.edu/docs/defaultsource/faculty-documents/robert-ennis/thenatureofcriticalthinking_51711_000.pdf.

Ennis, R. H. (2013). Critical thinking across the curriculum (CTAC). In D. Mohammed, \& M. Lewiński (Eds.), Virtues of Argumentation. Proceedings of the 10th International Conference of the Ontario Society for the Study of Argumentation (OSSA) (pp.1-16). Windsor, ON: OSSA.

Etkina, E., \& Planinsic, G. (2015). Defining and developing "critical thinking" through devising and testing multiple explanations of the same phenomenon. The Physics Teacher 53, 432. doi: 10.1119/1.4931014.

Firdaus, \& Darmadi. (2017). shaping scientific attitude of biology education students through research-based teaching. The 4th International Conference on Research, Implementation, and Education of Mathematics and Science. doi: 10.1063/1.4995214.

Furqani, D., Feranie, S., \& Winarno, N. (2018). The effect of predict-observe-explain (POE) strategy on students' conceptual mastery and critical thinking in learning vibration \& wave. Journal of science learning, 2(1), 1-8. doi: 10.17509/jsl.v2i1.12879.

Hacieminoglu, E. (2016). Elementary school students' attitude toward science and related variables. International Journal of Environmental and Science Education 11(2), 35-52. doi: 10.12973/ijese.2016.288a.

John, O. K., \& Ademola, O. R. (2014). Scientific attitude, attitude to science and science achievement of senior secondary school students in Katsina State, Nigeria. Journal of Educational and Social Research, 4(1), 445-452. http://dx.doi.org/10.5901/jesr.2014.v4n1p445.

Klein, G. (2011). Critical thoughts about critical thinking. Theoretical Issues in Ergonomics Science, 12(3), 210224. https://doi.org/10.1080/1464536X.2011.564485.

Kuşdemir, M., Yusuf. A. Y., \& Tüysüz, C. (2013). An analysis of the effect of Problem based learning model on the 10th-grade students' achievement, attitude, and motivation in the unit of "mixtures". Necatibey Faculty of Education, Electronic Journal of Science and Mathematics Education, 7(2), 195-224. http://dx.doi.org/10.12973/nefmed207.

Lloyd, M., \& Bahr, N. (2010). Thinking critically about critical thinking in higher education. International Journal for the Scholarship of Teaching and Learning, 4(2), 119, https://doi.org/10.20429/ijsotl.2010.040209.

Mahulae, P. S., Sirait, M., Sirait, M. (2017). The effect of inquiry training learning model using PhET media and scientific attitude on students' science process skills. IOSR Journal of Research \& Method in Education 7(5), 24-29. doi: 10.9790/73880705012429

Panneerselvam, M. \& Muthamizhselvan, M. (2015). The secondary school students in relation to scientific attitude and achievement in science. IOSR Journal of Research \& Method in Education, 5(2), 05-08. doi: 10.9790/7388-05210508 
Peter, E. (2012). Critical thinking: essence for teaching mathematics and mathematics problem solving skills. African Journal of Mathematics and Computer Science Research, 5(3), 39-43. https://doi.org/10.5897/AJMCSR11.161.

Potvin, P., \& Hasni, A. (2014). Analysis of the decline in interest towards school science and technology from grades 5 through 11. Journal of Science Education and Technology, 23(6), 784-802. doi: 10.1007/s10956-014-9512-x.

Qarareh, O. A. (2016). The effect of using the constructivist learning model in teaching science on the achievement and scientific thinking of 8th grade students International Education Studies, 9(7) 178-196. http://dx.doi.org/10.5539/ies.v9n7p178.

Sahyar, Ridwan A., Sani, \& Malau, T. (2017). The effect of PBL model and SRL toward physics problem solving ability of students at senior high school. American Journal of Educational Research, 5(3), 279-283. doi: 10.12691/education-5-3-8.

Şentürk, E., \& Özdemir, Ö. F. (2014). The effect of science centers on students' attitudes towards science. International Journal of Science Education, Part B: Communication and Public Engagement, 4(1), 1-24. https://doi.org/10.1080/21548455.2012.726754.

Şeşen, B. A., \& Mutlu, A. (2016). Predict-observe-explain tasks in chemistry laboratory: pre-service elementary teachers' understanding and attitudes. Sakarya University Journal of Education, 6(2), 184-208. http://dx.doi.org/10.19126/suje.46187.

Scott, L. (2015). Future learning 3: What kind of learning for the $21^{\text {st }}$ century? Education and Research: UNESCO.

Suarniati. W. N., Hidayah, N., \& Handarini, D. (2018). the development of learning tools to improve students' critical thinking skills in vocational high school. IOP Conf. Series: Earth and Environmental Science, 175, 012095 doi: 10.1088/17551315/175/1/012095.

Üstün, U., \& Eryilmaz, A. (2014). A research method to do effective research synthesis: Meta-analysis. Education and Science, 174(39), 1-32. doi: 10.15390/EB.2014.3379.

Vieira, R. M., \& Vieira, C. T. (2016). Fostering scientific literacy and critical thinking in elementary science education. International Journal of Science and Mathematics Education 14, 659-680. http://dx.doi.org/10.1007/s10763-014-9605-2.

Vossen, T. E., Henze, I., Rippe, R. C. A., Van Driel, J. H., \& De Vries, M. J. (2018). Attitudes of secondary school students towards doing research and design activities. International Journal of Science Education, 1-25. doi: 10.1080/09500693.2018.1494395.

Zubaidah, S., Corebima, A. D., Mahanal, S., \& Mistianah. (2018). Revealing the relationship between reading interest \& critical thinking through remap GI \& Jigsaw. International Journal of Instruction, 11(2), 41-56. https://doi.org/10.12973/iji.2018.1124a. 